\title{
Profil Kejang Pasca Stroke pada Pasien Rawat Inap Periode Juli 2018 - Juni 2019 di RSUP Prof. Dr. R. D. Kandou Manado
}

\author{
Jeremia A. Tombeng, ${ }^{1}$ Corry N. Mahama, ${ }^{2}$ Mieke A. H. N. Kembuan ${ }^{2}$
}

\author{
${ }^{1}$ Program Studi Pendidikan Dokter Fakultas Kedokteran Universitas Sam Ratulangi Manado \\ ${ }^{2}$ Bagian Neurologi Fakultas Kedokteran Universitas Sam Ratulangi Manado \\ Email: tombeng.jeremiah11@gmail.com
}

\begin{abstract}
Stroke is the most common cause of seizures in elderly population. The higher the number of stroke patients, the higher the predicted level of likelihood of the prevalence of poststroke seizures. This study was aimed to obtain the profile of post-stroke seizures among hospitalized patients from July 2018 to June 2019 at Prof. Dr. R. D. Kandou Hospital Manado. This was a descriptive and retrospective study. The results showed 24 patients who met the inclusion criteria. Post-stroke seizures were more common in males than in females. Based on age, most patients with post-stroke seizures were in the age range of 45-54 years. Many poststroke seizure patients worked as housewives. Most post-stroke seizure patients suffered from focal seizures with impaired awareness. Among patients with post-stroke seizures, the number of patients with ischemic stroke type was higher than of patients with hemorrhagic stroke type. In conclusion, the majority of patients were males, aged 45-54 years, had focal seizures and impaired awareness, as well as ischemic stroke. The most common job of the patients was housewifery.
\end{abstract}

Keywords: stroke, seizures, post-stroke seizures

\begin{abstract}
Abstrak: Stroke merupakan penyebab kejang yang paling umum pada populasi lansia. Semakin tinggi data yang menunjukkan jumlah pasien stroke, maka tingkat kemungkinan prevalensi terjadinya kejang pasca stroke juga diprediksi akan meningkat. Penelitian ini bertujuan untuk mengetahui profil kejang pasca stroke pada pasien rawat inap periode Juli 2018-Juni 2019 di RSUP Prof. Dr. R. D. Kandou Manado. Jenis penelitian ialah deskriptif retrospektif. Hasil penelitian memperoleh 24 pasien yang memenuhi kriteria inklusi. Jumlah pasien kejang pasca stroke lebih banyak pada laki-laki dibandingkan perempuan. Berdasarkan usia pasien kejang pasca stroke terbanyak berada dalam rentang usia 45-54 tahun. Berdasarkan pekerjaan, pasien kejang pasca stroke terbanyak bekerja sebagai ibu rumah tangga. Sebagian besar pasien kejang pasca stroke mengalami kejang fokal dengan kesadaran terganggu. Jumlah pasien kejang pasca stroke dengan tipe stroke iskemik lebih banyak dibandingkan tipe stroke hemoragik. Simpulan penelitian ini ialah mayoritas pasien dengan kejang pasca stroke berjenis kelamin laki-laki, berusia 45-54 tahun, tipe kejang fokal dengan kesadaran terganggu, dan tipe stroke iskemik. Pekerjaan yang terbanyak didapatkan ialah ibu rumah tangga.
\end{abstract}

Kata kunci: stroke, kejang pasca stroke

\section{PENDAHULUAN}

Kejang dan epilepsi merupakan salah satu kondisi dari beberapa gangguan yang sering terjadi pada sistem saraf dan lazim ditemukan di seluruh dunia. Berdasarkan data WHO tahun 2018, sekitar 50 juta penduduk di dunia mengalami gangguan epilepsi, ${ }^{1}$ yang semakin terus bertambah. Puncak pengidap epilepsi terjadi pada usia antara 2 tahun sampai lebih dari 65 tahun. Angka prevalensi epilepsi di Indonesia tidak jauh berbeda dari negara-negara Asia lainnya seperti Pakistan dan Thailand yaitu antara 3,9-5,6 per 1.000 orang. Data preva- 
lensi epilepsi di Provinsi Sulawesi Utara dalam kurun waktu 1 tahun (periode Juli 2015-Juni 2016) ialah 297 kasus berdasarkan data pasien Poliklinik Saraf RSUP Prof. Dr. R. D. Kandou. ${ }^{2}$

Epilepsi dapat didefinisikan sebagai adanya gangguan aktivitas listrik otak yang dapat menyebabkan kejang. Terdapat beberapa faktor pencetus penyebab epilepsi secara umum, yaitu faktor genetik, trauma kepala, tumor otak, stroke, gangguan perkembangan pada anak, cedera prenatal, dan juga penyakit menular seperti meningitis dan AIDS. Melalui beberapa faktor pencetus tersebut dapat disimpulkan bahwa kondisi epilepsi dapat terjadi pada siapapun dan dimana saja. Adanya riwayat penyakit stroke menjadi salah satu kondisi medis yang dapat berperan sebagai faktor pemicu terjadinya epilepsi. Stroke dikatakan sebagai terganggunya pasokan darah di otak sehingga fungsi otak hilang dan mengganggu aktivitas otak. Dengan demikian, pasien yang memiliki riwayat stroke juga rentan terkena epilepsi. ${ }^{3-5}$

Penyakit stroke telah semakin sering dijumpai. Hal ini dapat ditunjukkan melalui angka prevalensi stroke yang meningkat dari $7 \%$ menjadi $10,9 \%$ pada data Riskesdas tahun 2018. Data tersebut memperlihatkan bahwa Provinsi Sulawesi Utara menempati peringkat ketiga se-Indonesia. ${ }^{6}$

Dari definisi kondisi epilepsi dan stroke dapat disimpulkan adanya korelasi di antara kedua penyakit tersebut. Stroke merupakan penyebab paling umum kejang pada populasi lansia. ${ }^{4}$ Penelitian Oxford-shire Community Stroke Project menun-jukkan bahwa $11,5 \%$ pasien dengan stroke memiliki risiko terkena kejang pascastroke. ${ }^{4}$ Semakin tinggi data yang menunjukkan jumlah pasien stroke, maka tingkat kemungkinan prevalensi terjadinya epilepsi juga diprediksi akan meningkat. Umumnya stroke terjadi pada pasien dewasa dan lansia dengan fungsi organ-organ tubuh sudah semakin menurun. Adanya riwayat stroke pada lansia akan membuat mereka lebih rentan mengidap epilepsi serta meningkatkan bahaya. $^{4}$

Bertolak dari hal-hal yang telah dipa- parkan maka penulis tertarik untuk melakukan penelitian tentang profil penderita kejang pasca stroke di RSUP Prof. Dr. R. D. Kandou Manado periode Juli 2018 s/d Juni 2019.

\section{METODE PENELITIAN}

Penelitian ini dilakukan di RSUP Prof. Dr. R. D. Kandou Manado sejak bulan November s/d Desember 2019. Jenis penelitian ini ialah deskriptif retrospektif, yaitu dengan menggunakan data rekam medik RSUP Prof. Dr. R. D. Kandou Manado. Populasi penelitian ialah semua pasien kejang dengan riwayat stroke di RSUP Prof. Dr. R. D. Kandou Manado periode Juli 2018-Juni 2019. Pasien dengan riwayat epilepsi sebelum stroke dan adanya gangguan metabolik dieksklusi dari penelitian. Variabel penelitian yang diteliti ialah jumlah pasien, jenis kelamin, usia, pekerjaan, jenis kejang, dan diagnosis tipe stroke.

Penelitian ini telah mendapat persetujuan dari Komisi Etik Penelitian Kesehatan RSUP Prof. Dr. R. D. Kandou Manado, dengan nomor keterangan layak etik yaitu No. 098/EC/KEPK-KANDOU/XII/2019.

\section{HASIL PENELITIAN}

Berdasarkan hasil penelitian secara retrospektif yang dilakukan selama bulan Desember 2019 di Irina F Neurologi dan Instalasi Rekam Medik RSUP Prof. dr. R. D. Kandou Manado dengan cara mendata catatan rekam medik. Terdapat 400 pasien dengan diagnosis stroke yang dirawat di Irina F Neurologi periode Juli 2018-Juni 2019, sebanyak 183 pasien yang memenuhi data rekam medik, dan yang memenuhi kriteria inklusi sebanyak 24 pasien.

Data penelitian ini menunjukkan $13,11 \%$ dari pasien stroke mengalami kejang. Jumlah pasien berjenis kelamin lakilaki lebih banyak dibandingkan perempuan, yaitu 13 pasien laki-laki $(54,17 \%)$ dan 11 pasien perempuan $(45,83 \%)$ dengan perbandingan 1,18:1.

Tabel 1 memperlihatkan bahwa kelompok usia pasien kejang pasca stroke terbanyak terdapat pada kelompok usia 4554 berjumlah 9 pasien $(37,50 \%)$ dan yang 
paling sedikit ialah kelompok usia 25-34 tahun serta kelompok usia $>74$ tahun masing-masing berjumlah 1 pasien $(4,17 \%)$. Pada kelompok usia $<25$ tahun tidak ditemukan pasien.

Tabel 1. Distribusi pasien kejang pasca stroke berdasarkan usia

\begin{tabular}{ccc}
\hline Usia & Jumlah & $(\boldsymbol{\%})$ \\
\hline$<25$ & 0 & 0,00 \\
$25-34$ & 1 & 4,17 \\
$35-44$ & 3 & 12,50 \\
$45-54$ & 9 & 37,50 \\
$55-64$ & 8 & 33,33 \\
$65-74$ & 2 & 8,33 \\
$>74$ & 1 & 4,17 \\
Total & 24 & 100 \\
\hline
\end{tabular}

Tabel 2 menunjukkan distribusi pasien kejang pasca stroke berdasarkan pekerjaan, dan didapatkan pasien terbanyak bekerja sebagai ibu rumah tangga berjumlah 7 pasien $(29,17 \%)$, dan yang paling sedikit ialah buruh berjumlah 1 pasien $(4,17 \%)$.

Tabel 2. Distribusi pasien kejang pasca stroke berdasarkan pekerjaan

\begin{tabular}{ccc}
\hline Pekerjaan & Jumlah & $\mathbf{( \% )}$ \\
\hline Pelajar/mahasiswa & 0 & $0,00 \%$ \\
Pegawai negeri & 3 & $12,50 \%$ \\
sipil & 5 & $20,83 \%$ \\
Pegawai swasta & 4 & $16,67 \%$ \\
Wiraswasta & 0 & $0,00 \%$ \\
Pensiunan & 7 & $29,17 \%$ \\
Ibu rumah tangga & 4 & $16,67 \%$ \\
Petani & 1 & $4,17 \%$ \\
Buruh & 0 & $0,00 \%$ \\
Tidak bekerja & 0 & $0,00 \%$ \\
Pelajar/mahasiswa & 000 \\
Total & 24 & 100 \\
\hline
\end{tabular}

Tabel 3 menunjukkan distribusi pasien kejang pasca stroke berdasarkan jenis kejang. Terdapat 17 pasien $(70,83 \%)$ dengan kejang fokal dan terdapat 7 pasien $(29,17 \%)$ dengan kejang umum.

Tabel 4 memperlihatkan 17 pasien dengan kejang fokal, dan didapatkan 14 pasien $(82,36 \%)$ kejang fokal dengan kesa- daran terganggu dan 3 pasien $(17,65 \%)$ kejang fokal tanpa gangguan kesadaran.

Tabel 3. Distribusi pasien kejang pasca stroke berdasarkan jenis kejang

\begin{tabular}{ccc}
\hline Jenis kejang & Jumlah & $(\boldsymbol{\%})$ \\
\hline Fokal & 17 & $70,83 \%$ \\
Umum & 7 & $29,17 \%$ \\
Jumlah & 24 & $100 \%$ \\
\hline
\end{tabular}

Tabel 4. Distribusi pasien kejang pasca stroke berdasarkan jenis kejang fokal.

\begin{tabular}{ccc}
\hline $\begin{array}{c}\text { Jenis } \\
\text { kejang fokal }\end{array}$ & Jumlah & $(\boldsymbol{\%})$ \\
\hline $\begin{array}{c}\text { Sadar } \\
\text { Gangguan }\end{array}$ & 3 & $17,65 \%$ \\
kesadaran & 14 & $82,36 \%$ \\
Jumlah & 17 & $100,00 \%$ \\
\hline
\end{tabular}

Seluruh pasien kejang fokal tanpa gangguan kesadaran mengalami kejang onset motorik tonik. Pada pasien kejang fokal dengan kesadaran terganggu, didapatkan 13 pasien $(92,86 \%)$ kejang fokal tonik dengan kesadaran terganggu dan 1 pasien $(7,14 \%)$ kejang fokal bilateral tonikklonik dengan gangguan kesadaran. Pada pasien dengan kejang umum didapatkan seluruh pasien termasuk dalam kejang umum tonik-klonik.

Tabel 5 memperlihatkan distribusi pasien kejang pasca stroke berdasarkan tipe stroke. Tipe stroke iskemik terdapat pada 15 pasien $(62,5 \%)$ sedangkan tipe stroke hemoragik pada 9 pasien $(37,5 \%)$.

Tabel 5. Distribusi pasien kejang pasca stroke berdasarkan tipe stroke

\begin{tabular}{ccc}
\hline Tipe stroke & Jumlah & $(\boldsymbol{\%})$ \\
\hline Iskemik & 15 & $62,5 \%$ \\
Hemoragik & 9 & $37,5 \%$ \\
Jumlah & 24 & $100 \%$ \\
\hline
\end{tabular}

\section{BAHASAN}

Hasil penelitian ini mendapatkan 24 pasien kejang pasca stroke dari 183 pasien stroke. Data tersebut menunjukkan 13,11\% dari pasien stroke mengalami kejang. Salah satu penelitian terbesar dan paling ketat 
mengenai kejang pasca stroke yaitu laporan multisenter prospektif dari kelompok studi Seizure After Stroke Study Group yang dilakukan oleh Bladin et al. ${ }^{3}$ Penelitian tersebut melaporkan insiden kejang sebesar 8,9\% dari 1897 pasien stroke. Penelitian oleh Silvermann et $\mathrm{al}^{7}$ mendapatkan dari data registrasi stroke, yaitu sekitar 5-20\% dari semua individu yang mengalami stroke akan mengalami kejang berikutnya. Demikian pula penelitian Oxfordshire Community Stroke Project (OCSP) melaporkan bahwa $11,5 \%$ pasien dengan stroke berisiko mengembangkan kejang pasca stroke. ${ }^{4}$

Hasil penelitian ini mendapatkan bahwa berdasarkan jenis kelamin, pasien kejang pasca stroke yang dirawat inap di Irina $\mathrm{F}$ Neurologi RSUP Prof. Dr. R. D. Kandou Manado periode Juli 2018-Juni 2019 lebih banyak yang berjenis kelamin laki-laki dibandingkan perempuan dengan perbandingan 1,18;1. Umumnya, perban-dingan pasien stroke antara jenis kelamin laki-laki dan perempuan hampir sama. ${ }^{5}$ Data Riset Kesehatan Dasar (Riskesdas) menunjukkan bahwa di Indonesia perbandingan pasien stroke jenis kelamin laki-laki dan perempuan tidak jauh berbeda dan persentase pasien stroke jenis kelamin laki-laki sedikit lebih banyak dibandingkan perempuan. ${ }^{6}$ Hasil penelitian Feyissa et $\mathrm{al}^{8}$ mendapatkan prevalensi pasien kejang pasca stroke dengan jenis kelamin laki-laki lebih tinggi dibandingkan perempuan.

Hasil penelitian ini mendapatkan bahwa distribusi berdasarkan usia terbanyak pada kelompok usia 45-54 tahun $(37,50 \%)$, disusul kelompok usia 55-64 tahun $(33,33 \%)$, kelompok usia 35-44 tahun $(12,50 \%)$, kelompok usia 65-74 tahun $(8,33 \%)$, dan kelompok usia 25-34 tahun serta kelompok usia $>74$ tahun (masingmasing 4,17\%). Pada kelompok usia <25 tahun tidak ditemukan pasien. (Tabel 1). Stroke merupakan penyebab kejang yang paling umum pada lansia. ${ }^{9,10}$ Hasil penelitian ini didukung oleh penelitian Tanaka et $\mathrm{al}^{11}$ yang melaporkan insiden kejang pasca stroke lebih tinggi pada pasien berusia $<65$ tahun dibandingkan 85 tahun ke atas. Faktor-faktor risiko yang diketahui berpe- ran pada usia $<65$ tahun untuk terjadinya kejang pasca stroke ialah hiponatremia, subtipe stroke hemoragik, konsumsi alkohol, keterlibatan kortikal, dan keparahan stroke. $^{8}$

Hasil penelitian ini mendapatkan bahwa berdasarkan pekerjaan, distribusi pasien kejang pasca stroke terbanyak bekerja sebagai ibu rumah tangga $(29,17 \%)$, diikuti pegawai swasta $(20,38 \%)$, petani $(16,67 \%)$, wiraswasta $(16,67 \%)$, pegawai negeri sipil $(12,50 \%)$, dan buruh $(4,17 \%)$ (Tabel 2). Data Riskesdas menunjukkan bahwa jumlah pasien stroke banyak terdapat pada golongan yang tidak bekerja diikuti dengan pegawai negeri sipil, pekerjaan lainnya, dan wiraswasta. ${ }^{6}$ Pada penelitian ini, golongan pekerjaan terbanyak (ibu rumah tangga) tidak masuk dalam 4 besar golongan pekerjaan yang didata oleh Riskesdas. Prevalensi terjadinya stroke dikaitkan dengan gaya hidup dan aktivitas seseorang yang termasuk dalam faktor risiko terjadinya stroke yang dapat dimodifikasi. ${ }^{5}$

Berdasarkan jenis kejang, pada hasil penelitian ini didapatkan kejang dengan onset fokal sebanyak 17 pasien $(70,83 \%)$ dan kejang umum sebanyak 7 pasien $(29,17 \%)$. Dari 17 pasien kejang fokal, didapatkan 14 pasien $(82,36 \%)$ kejang fokal dengan kesadaran terganggu dan 3 pasien $(17,65 \%)$ kejang fokal tanpa gangguan kesadaran (Tabel 3). Dari 3 pasien kejang fokal tanpa gangguan kesadaran, didapatkan data sebesar $100 \%$ pasien termasuk dalam kejang tonik. Dari hasil penelitian ini, pasien kejang fokal dengan gangguan kesadaran, didapatkan 13 pasien $(92,86 \%)$ kejang fokal tonik dengan gangguan kesadaran dan 1 pasien $(7,14 \%)$ kejang fokal ke bilateral tonik-klonik dengan gangguan kesadaran. Seluruh pasien dengan kejang umum mengalami kejang umum dengan onset motorik tonik-klonik. Penelitian oleh Silverman et $\mathrm{al}^{7}$ mengemukakan bahwa kejang pasca stroke paling banyak disebabkan oleh lesi fokal, dan kejang pasca stroke biasanya merupakan onset fokal. ${ }^{7}$ Dalam studi kejang onset dini, kejang parsial sederhana (simple partial seizures) ialah jenis yang paling umum, diikuti oleh kejang 
umum sekunder (secondarily generalized seizures), serta kejang umum tonikklonik. $^{4,7,8}$ Kejang umum tonik-klonik lebih sering terjadi pada kejang onset lanjut. ${ }^{4}$ Hasil penelitian ini sesuai dengan penelitian Silverman et $\mathrm{al}^{7}$ yang menyatakan bahwa kejadian jenis kejang terbanyak ialah onset fokal. Namun, pada onset fokal yang ditemukan pada penelitian ini, lebih banyak pasien yang mengalami gangguan kesadaran saat kejang sedangkan pada kepustakaan ditemukan kejang parsial sederhana atau yang sekarang dikenal sebagai kejang fokal tanpa disertai gangguan kesadaran. Pada penelitian ini juga didapatkan kejang umum sekunder atau yang sekarang dikenal sebagai kejang fokal bilateral tonik-klonik serta kejang umum tonik-klonik yang sesuai dengan kepustakaan.

Distribusi pasien kejang pasca stroke berdasarkan tipe stroke mendapatkan bahwa pasien dengan tipe stroke iskemik lebih banyak dibandingkan dengan tipe stroke hemoragik. Kejang pasca stroke dengan tipe stroke iskemik terdapat pada 15 pasien $(62,5 \%)$ sedangkan tipe stroke hemoragik berjumlah 9 pasien $(37,5 \%)$ (Tabel 5). Berdasarkan kepustakaan, tipe stroke yang memberi andil dalam faktor risiko terjadinya kejang pasca stroke ialah tipe stroke hemoragik. $^{12}$ Pada penelitian ini, pasien kejang pasca stroke dengan tipe stroke iskemik lebih banyak dibandingkan dengan tipe stroke hemoragik. Perbedaan hasil penelitian ini dengan kepustakaan diduga karena faktor-faktor risiko yang meningkatkan persentase terjadinya kejang pasca stroke tidak hanya tipe stroke tetapi juga tingkat keparahan stroke, lokasi lesi, faktor risiko vaskuler, serta faktor genetik. ${ }^{12}$

\section{SIMPULAN}

Pada penelitian terhadap pasien kejang pasca stroke di ruang rawat inap Irina $F$ Neurologi RSUP Prof. Dr. R. D. Kandou Manado periode Juli 2018-Juni 2019 didapatkan bahwa yang terbanyak ialah pasien berjenis kelamin laki-laki, rentang usia 4554 tahun, mengalami kejang fokal dengan kesadaran terganggu, dan dengan tipe stroke iskemik. Pekerjaan yang terbanyak ialah sebagai ibu rumah tangga.

Perlu dilakukan follow up terhadap pasien dan rekam medik yang diperbaharui sehingga pasien dengan late onset atau kejang berulang tetap terdata.

\section{Konflik Kepentingan}

Penulis menyatakan tidak terdapat konflik kepentingan dalam studi ini.

\section{DAFTAR PUSTAKA}

1. WHO. WHO/Epilepsy: a public health imperative. Geneva: World Health Organization, 2019; p.1-2.

2. Hasibuan M, Mahama C, Tumewah R. Profil penyandang epilepsi di Poliklinik Saraf RSUP Prof . Dr . R . D . Kandou. e-CliniC. 2016;4(2).

3. Bladin C, Alexandrov A, Bellavance A, Bornstein N, Chambers B, Cote R, et al. Seizures after stroke. Arch Neurol. 2012;57:1617-22.

4. Myint PK, Staufenberg EFA, Sabanathan K. Post-stroke seizure and post-stroke epilepsy. Postgrad Med J. 2006; 82(971):568-72.

5. Parmar P. Stroke: classification and diagnosis. Clin Pharm. 2011;3:200-15.

6. Kementerian Kesehatan RI. Laporan Hasil Riset Kesehatan Dasar (Riskesdas) Indonesia tahun 2018. Jakarta: Badan Penelitian dan Pengembangan Kesehatan Kemenkes RI, 2018; p. 164-8.

7. Silverman IE, Restrepo L, Mathews GC. Poststroke seizures. Arch Neurol. 2002; 59:195-202.

8. Feyissa AM, Hasan TF, Meschia JF. Strokerelated epilepsy. Eur J Neurol. 2019; 26(1):18-29.

9. Castro-Apolo R, Huang JF, Vinan-Vega M, Tatum WO. Outcome and predictive factors in post-stroke seizures: A retrospective case-control study. Seizure Eur J Epilepsy. 2018;62(61):11-6.

10. Menon B, Shorvon SD. Ischaemic stroke in adults and epilepsy. Epilepsy Res. 2009; 87(1):1-11.

11. Tanaka T, Ihara M. Post-stroke epilepsy. Neurochem Int. 2017;(1):1-10.

12. Zhao Y, Li X, Zhang K, Tong T, Cui R. The Progress of Epilepsy after Stroke. Curr Neuropharmacol. 2017;16(1):71-8. 